\title{
Conditional Cash Transfer (CCT) Program: Students Perception and Challenges in their Academic Performance
}

\author{
Maria Elena G. Corpuz, Joane R. Malilay, Marjorie C.Garancho, Jennifer G. \\ Fronda, Mercedes D. Santos
}

\begin{abstract}
This study focused on conditional cash transfer (CCT) program implementation to the studentrecipients in the five selected public secondary schools in a certain Congressional District in the Division of Nueva Ecija, Philippines. The data gathered revealed that the amount of Php500 (10U\$) CCT cash grant is insufficient for the respondents' school needs and most of the time this amount had been used for the food budget of the family. This resulted in absences and non-compliance to school activities and requirements of the students which negatively affect their academic performance.
\end{abstract}

Keywords-Academic performance, absences, conditional cash transfer, secondary school.

\section{INTRODUCTION}

The conditional cash transfer (CCT) also known as 4P's program is one of the programs implemented in the Philippines under the Department of Social Welfare and Development (DSWD)[1]. The program was commonly known as Pantawid Pamilyang Pilipino Program or simply 4P's that transfer cash to poorest of the poor families on the condition that their children attend to school and visit a health facility for health check-ups and services, such as growth monitoring and vaccination, attend to family improvement seminars and such services offered by the government [2].In general, CCT program is a social program agreement wherein the government provided financial funds and recipients obliged to the fulfillment in an exchange of certain task of securing their children attendance in school, attendance to family development sessions (FDS), regular health check-up in the nearest community health center, active participation in any government-sponsored program like feeding and community cleaning programs and securing attendance in more specific trainings and livelihood programs[3].

Taberna (2012) [4], stated that the beneficiaries of 4P's are the poorest of the poor and 1,400, is and it will be a big help for them although it may not be enough. Additionally, it also says that the maximum amount of cash grant represents only 7 percent of the beneficiary household's average income prior to its receipt [5]. Alongside the positive experiences with the program, are the criticisms of CCTs. One of these is paternalism: imposing conditions to change the behavior of the poor implies that the poor are unaware of what is beneficial to them, and cash incentives are necessary for them to act on what is to their best interest [6]. A limitation of most CCT evaluations is that the program under study is relatively new, and the behavioral changes were measured while the participants were still in the program [7].

However, in reality, this program cannot guarantee its complete effectiveness among its beneficiaries because there are some who are using the money in another means instead of its actual purpose which is for the educational needs of the students resulting in their performance and school attendance to suffer[8]. As the researchers' personal experiences and observations in day to day activities of students who are 4P's members had poor class attendance and had difficulties to comply in different school activities and projects because of their reasons for financial problems.

It cannot be denied that all public schools from elementary to senior high school offered free education for all. It is a great privilege and opportunity for all learners to be educated particularly those who under the senior high school wherein the knowledge and skills they will acquire, will have great use for their future. Senior High School offered different track/strands depending on the program offered by the school 
to cater to the varied needs of the students[9]. With this, there will be no reason for the youth not to go to school. But even though that there are learners not attending their class regularly and had a poor academic performance the government still finds ways to help the poorest of the poor to sustain the educational needs of every child even in small financial assistance[10]. The researchers come up with this study to determine the perceptions and challenges encountered by conditional cash transfer student recipients. Specifically, this study sought to: determine the sociodemographic status of the respondents; describe the Conditional Cash Transfer (CCT) Program; and determine the challenges encountered by respondents on the use of the cash grants.

\section{METHODOLOGY}

This study utilized a descriptive research design to gather data relevant to answer the problem of the study. In selecting the sample respondents, the researchers used a purposive sampling technique [12]. A total of 108 grade 12 students, 15 advisers, and 5 coordinators were selected as respondents coming from five selected public secondary schools in a certain Congressional District in the Division of Nueva Ecija, Philippines. The data coming from advisers and coordinators were used for validation purposes. A survey questionnaire and unstructured interview served as the instrument to gather the data. These were personally designed, developed, and validated by the researchers. The questionnaire was accompanied by a letter stating the purpose of the survey and was personally administered by the researchers. The respondents were briefed on the significance of the survey so Furthermore, almost half 75 (69.44\%) of the recipients have other sources of allowance coming from their parents' income that helps sustain their educational needs. They also that the researchers would elicit honest responses from them. The data were then tabulated and analyzed thru data analysis using frequency count and percentage.

\section{RESULTS AND DISCUSSION}

\section{Socio-Demographic Profile of the Respondents}

The majority of 4Ps student-beneficiaries were female, aged 16 and 17, attended their class twice and thrice a week with Php41.00 (U\$0.82) to Php60.00 (U\$1.20) daily allowance. Household size is five for every family. As to their parents' occupation, most of them were drivers and construction workers who earned a monthly income which was found to be below Php10,000 (less than \$200). Most of them reached secondary education.

\section{Conditional Cash Transfer Grants}

\subsection{Respondents' Perception in the Utilization of CCT}

The survey conducted to the students regarding their perception in the utilization of CCT cash grants where 89 $(82.41 \%)$ answered "sometimes" that their parent spent money on other (unnecessary) expenses for their own satisfaction like vices, but despite this suspicion, they still eat meals three times a day 92 (85.19\%). All 108 (100\%) of them said that Php500 is not enough to support or sustain their educational needs because of some school projects and activities. They even disclosed that their transportation allowance is insufficient, and a great part $97(89.81 \%)$ are discontented with the amount of money that they are receiving from the CCT program. However, 88 (81.48\%) said that the cash grants are a big help too as this lessens their burden in money in going to school.

claimed that CCT programs have become ineffective in helping them attend their classes regularly.

Table 1.Respondents' Perception in the Utilization of CCT

\begin{tabular}{|l|c|c|l|c|c|}
\hline $\begin{array}{l}\text { Do you think that the CCT being received } \\
\text { by your parents is spent on other expenses } \\
\text { instead of food and educational needs? }\end{array}$ & $\mathbf{f}$ & $\boldsymbol{\%}$ & $\begin{array}{l}\text { Do you think that the CCT cash grant is } \\
\text { really helpful to a student like you? }\end{array}$ & f & $\%$ \\
\hline Always & 9 & 8.33 & Always & 88 & 81.48 \\
\hline Sometimes & 89 & 82.41 & Sometimes & 0 & 0 \\
\hline Never & 10 & 9.26 & Never & 20 & 18.52 \\
\hline Total & 108 & 100 & Total & 108 & 100 \\
\hline
\end{tabular}


Does your family eat three (3) times a day?

Always

Sometimes

Never

Total

Does the CCT allowance of Php $\mathbf{5 0 0 . 0 0}$ is enough for your educational needs?

Always

Sometimes

Never

Total

Are you contented with the amount of money that you are receiving from the CCT program?

Yes

No

Total

\section{|}

92

16

\begin{tabular}{|c|c|c|}
\hline 0 & \\
\hline 108 & 1
\end{tabular}

\begin{tabular}{|c|l|}
\hline 85.19 & Yes \\
\hline 14.81 & No \\
\hline 0 & Others
\end{tabular}

Aside from the CCT cash grants, do you have any source of allowance?

\begin{tabular}{|c|c|c|} 
& & \\
\hline & 75 & 69.44 \\
\hline 11 & 10.19 \\
\hline 22 & 20.37 \\
\hline 108 & 100
\end{tabular}

\section{Academic Performance}

Table 2 shows the data on the academic performance of student-respondents based on their final rating during the $2^{\text {nd }}$ Semester of S.Y. 2019-2020. It shows that less than half or $42(38.89 \%)$ of them got a final average that ranges from 75-79 interpreted as "fairly

Table 2. Students' Academic Performance

\begin{tabular}{|c|c|c|c|}
\hline Academic Performance & Frequency & Percent & Verbal Description \\
\hline $90-100$ & 19 & 17.59 & Outstanding \\
\hline $85-89$ & 29 & 26.85 & Very Satisfactory \\
\hline $80-84$ & 18 & 16.67 & Satisfactory \\
\hline $75-79$ & 42 & 38.89 & Fairly Satisfactory \\
\hline Below 75 & 0 & 0.00 & Did not meet Expectations \\
\hline Total & 108 & 100 & \\
\hline
\end{tabular}

satisfactory" based on the Department of Education school form number 9. This may imply that the CCT cash grants had an effect on student's attendance because of their common reason for missing their classes due to lack of money to support their educational needs.
Does the CCT program help you to improve your academic performance?
Do you think that the CCT program really helps you to attend your class regularly?

\begin{tabular}{|l|c|c|}
\hline Always & 11 & 10.19 \\
\hline Sometimes & 0 & 0 \\
\hline Never & 97 & 89.81 \\
\hline $\begin{array}{l}\text { Does the CCT program help you to } \\
\text { improve your academic performance? }\end{array}$ & 108 & 100 \\
\hline Yes & 11 & 10.19 \\
\hline No & 97 & 89.81 \\
\hline Total & 108 & 100 \\
\hline
\end{tabular}




\section{Challenges of 4P's Recipient-Students in Utilization of CCT Cash Grants}

Interviews conducted with the students further reveals that the main problem encountered [13] by majority or 97 (89.81) of the respondents are using CCT cash grants for their educational needs such as buying school supplies and materials, school uniforms, transportation expenses, and meal allowance. This is aggravated more because they still have to pay for school projects and some voluntary contributions. The cash grant allowance intended for this goes to buy food instead. They also claim that their parents have to spend, too, to satisfy their vices.

Conversations with their advisers and 4Ps school coordinators validate the claim of the students to be true because of the frequent absences these students committed, and the informal talks they had with them. This has led to their poor academic performance of students, they said.

\section{CONCLUSIONS AND RECOMMENDATIONS}

Most of the student-respondents were female, 16 and 17 years of age, attended their classes twice, and thrice a week with Php41.00 (U\$0.82) to Php60.00 (U\$1.20) allowance daily. Parents' educational attainment was mostly secondary level, while engaged in menial jobs with monthly income below Php10,000 (less than \$200). The average family size is five.

As to respondents' perception of CCT grants disclosed the amount was not enough to sustain their education, and they had the feeling that their parents had to spend still for their vices that had aggravated more the situation, other chunks of the earnings go-to food for the family.

Poor academic performance of students may be correlated to the parents' lack of resources.

It is recommended that the government may continue to support the program to help the students in their education, but with stricter policies to be effective [14]. This action is crucial for the country's economic growth and poverty reduction apparently cited in [15]. And also the DSWD should impose strict monitoring compliance of the school attendance as well as students' academic performance. Further, strict monitoring of the educational cash grants of students solely for this purpose. Moreover, student-recipients must be trained to face their challenges in order for them to solve meaningful problems and develop their higher-order thinking skills as they grow older [16], as cited in [17]. Lastly, the teachers, advisers, and 4Ps coordinators will have to continue helping students in their academic needs, emotional and spiritual side included, short of monetary school requirements to further ease their burden because of lack of money.

\section{REFERENCES}

[1] Albert, E. (2014), The Impact of Philippines' Conditional Cash Transfer Program on Consumptions.

[2] Agbon, A.B. et al (2013). Pantawid Pamilyang Pilipino Program (4P's): Examining Gaps and Enhancing Strategies in Cebu City, Philippines

[3] ADB 2008. Conditional Cash Transfer (CCT) Program: An Effective Tool for Poverty Alleviations?

[4] Alderman Harold, Friedman Jed, Filmer Deon, Junko Onishi, and Avalos Jorge (2016). A Conditional Cash Transfer Program in the Philippines Reduces Severe Stunting. The Journal of Nutrition, Volume 46, Issue 9, 2016. Retrieved from https://doi.org/10.3945/jn.116.233684

[5] Department of Social Welfare and Development (DSWD) ( 2012).PantawidPamilya Pilipino Program Results of Compliance Verification November and December 2011

[6] Department of Social Welfare and Development (2011) Project Implementation Plan for the Social Welfare and Development and Reform Project

[7] Montilla et al., (2015). PantawidPamilyang Pilipino Program (4P's): Assistance to Pupil's Education

[8] Santiago, M.D. (2010). Explanatory note. Fifteenth Congress of the Republic of the Philippines

[9] Scurring, E. (2010). Conditions, conditionality, conditionalities, responsibilities-finding common ground. Maastricht University, World Bank Philippines, Work Bank.

[10] World Health Organization (WHO, e-Library of Evidence for Nutrition Actions(ELENA)

[11] Subia, G., Mina. J., Diaz, R., Campos, Jr., R., and Quijano, G. (2019).Re-Engineering on the Production of Surrogate Feeds for Broiler Chickens (Gallus-Gallus Domesticus): its Effects on Broilers' Live and Carcass Weights and Consumption Cost. International Journal of Environment, Agriculture, and Biotechnology (IJEAB). Vol-4, Issue3.http://dx.doi.org/10.22161/ijeab/4.3.4 ISSN: 2456-1878.

[12] Abelardo, L., Lomboy, M., Lopez, C., Balaria, F., \& Subia, G. (2019). Challenges Encountered by the National High School Teachers in Doing Action Research. International Journal of English, Literature and Social Science (IJELS) Vol-4, Issue-4, Jul - Aug 2019 https://dx.doi.org/10.22161/ijels.4418 ISSN: 2456-7620.

[13] Subia, G. S. (2020). Fortuitous: A proposed activity-based book in mathematics of chance. International Journal of Scientific and Technology Research, 9(3), 450-45

[14] Ignacio, J., Santos, E., Socorro, P., Florencondia, N., Pascual, L. and Subia, G. (2019). Safety Measures and Safety Warning Signages of Road Construction Projects: An Assessment. 
International Journal of Advanced Engineering, Management, and Science (IJAEMS). Vol-5, Issue8.https://dx.doi.org/10.22161/ijaems.58.3 ISSN: 2454-1311.

[15] Salangsang, L. \& Subia, G.(2020). Mathematical thinking on problem-solving and self-regulation strategies of Filipino primary grade pupils. International Journal of Scientific \&Technology Research, Vol.9, Issue 2.

[16] Subia, G., Marcos, M., Valdez, A., Pascual, L. \& Liangco, M.(2020). Cognitive Levels as Measure of Higher-Order Thinking Skills in Senior High School Mathematics of Science, Technology, Engineering, and Mathematics (STEM) Graduates. Technology Reports of Kansai University. Volume 62, Issue 3, pp 261-268. 